\title{
A Igreja Bola de Neve e a vivência contemporânea do cristianismo
}

The Snowball Church and the contemporary experience of Christianity

Rossana Gomes Britto ${ }^{1}$

\section{Resumo}

Trata-se de um artigo sobre a vivência evangélica no Brasil contemporâneo, a partir do "boom" neopentecostal iniciado no século XX com seus desdobramentos atuais na sociedade. Neste artigo, também será apresentado um estudo de caso: A Igreja Bola de Neve, do município de Vila Velha, no Espírito Santo.

Palavras-chave: Igreja; Neopentecostalismo; Consumo; Consumo Experiencial.

\section{Abstract}

It is an article about the evangelical experience in contemporary Brazil, based on the neo-Pentecostal boom begun in the twentieth century with its current developments in society. In this article, a case study will also be presented: The Snowball Church, in the municipality of Vila Velha, in Espírito Santo.

Keywords: Church; Neopentecostalism; Consumption; Experiential Consumption.

${ }^{1}$ Professora de História do Brasil Colonial e disciplinas afins do Departamento de História da Universidade Federal do Espírito Santo. 
Religare, ISSN: 19826605, v.15, n.2, dezembro de 2018, p.451-482.

Diríamos que a experiência do sagrado torna possível a fundação do mundo.

Mircea Eliade

\section{Introdução}

A Felicidade Paradoxal, obra do filósofo francês Gilles Lipovetsky $(1944)^{2}$ levanta uma nova perspectiva sobre as motivações para o engajamento dos indivíduos para o consumo na era da hipermodernidade. Há um novo paradigma do consumo, paradigma que prioriza mais o ser do que o ter.

Essa configuração dos mercados de consumo estimula os desejos subjetivos dos indivíduos conferindo-lhes legitimidade e relacionando as possibilidades de realização de aspirações individuais com a aquisição das mais diversificadas mercadorias. Manifesta-se na confluência com o surgimento dos tempos de hiperconsumo um processo de compra desculpabilizada. É uma época em que o consumo não é somente de objetos, mas um consumo de natureza experiencial (COSTA, 2015, p. 4-5). ${ }^{3}$

Compra-prazer, consumo experiencial: como a compra pode ser uma atividade recreativa? Como pode funcionar como derivativo? O que faz do consumo um divertimento? Sem dúvida, a expansão do consumo hedonista não é separável das múltiplas estratégias comerciais. Com freqüência, sublinhou-se como a publicidade erotizava a mercadoria, criava um ambiente festivo, um clima de sonho acordado e de estimulação permanente dos desejos. Isso prossegue. A hora é da teatralização dos pontos das vendas, das animações diversas, do "marketing experiencial" tendo como objetivo criar uma ambiência de convívio e de desejos, introduzir prazer nos locais de

\footnotetext{
${ }^{2}$ Utilizamos a $70^{\circ}$ edição, de 2007, apresentada de forma completa nas referências.

${ }^{3}$ Disponível em: <www.abhr.org.br/plura/ojs/index.php/anais/article/view/1400/1007>. Acesso em: 06 de jul. de 2018.
} 
Religare, ISSN: 19826605, v.15, n.2, dezembro de 2018, p.451-482.

venda. Enquanto os especialistas anglo-saxões falam de "fun shopping", os centros comerciais e lojas da nova tendência se propõem a "reencantar" os gestos e locais de compra, a "transformar as zonas de tempo forçado em zonas de tempo- prazer". Porém, por mais importante que sejam, essas estratégias de venda não explicam tudo. A verdade é que existe um laço íntimo, estrutural, entre hiperconsumo e hedonismo: esse laço não é senão a mudança e a novidade estabelecidas em princípio generalizado tanto da economia material quanto da economia psíquica (LIPOVETSKY, 2007, p. 66-67, RODRIGUES, 2004).

Lipovetsky, embora não tenha realizado estudos sobre as religiões especificamente, tem uma reflexão interessante sobre a questão: $O$ que constitui o valor da religião não é mais sua posição de verdade absoluta, mas a virtude que lhe é atribuída de poder favorecer o acesso a um estado superior de ser, a uma vida subjetiva melhor, mais profunda e autêntica. Naturalmente - é útil sublinhá-lo - crer não é consumir: inscrevendo-se na continuidade de uma tradição, buscando o "essencial", o divino e o sentido da vida, o espírito de fé não pode ser confundido com o espírito pragmático do consumismo. Mas não é menos verdade, que a reafirmação contemporânea do religioso se acha marcada pelos próprios traços que definem o consumidor experiencial. Quem é ele: participação temporária, incorporação comunitária livre, comportamentos à la carte, primado do maior bem-estar subjetivo e da experiência emocional. Nesse plano, o Homo religiosus aparece mais como a continuação do Homo consumericus por outros meios (LIPOVETSKY, 2007, p. 132-133).

É importante notar a sensibilidade do autor em constatar no comportamento do sujeito religioso dos tempos hipermodernos, um comportamento que ele qualifica como estando pautado sobre três pilares principais: a "participação temporária, a incorporação comunitária livre 
Religare, ISSN: 19826605, v.15, n.2, dezembro de 2018, p.451-482.

e também os comportamentos à la carte", reflexos importantes que atingem a esfera da vivência religiosa contemporânea.

Na sociedade do hiperconsumo, a própria espiritualidade ganha um viéis do universo do consumo. Se é verdade que a reativação pós-moderna do religioso exprime certo desencanto com o materialismo da vida cotidiana, o certo é que o fenômeno é cada vez menos exterior à lógica mercantil. A espiritualidade se tornou mercado, produto a ser comercializado, setor a ser gerido e promovido (LIPOVETSKY, 2007, p. 132).

As constatações de Lipovetsky descrevem o relevante cenário social hodierno, sobretudo no que diz respeito à sociedade de consumo. No entanto, verificou-se que sua obra também focaliza aspectos para uma compreensão mais lúcida do campo religioso evangélico neopentecostal no Brasil. Desta forma, a teoria do consumo que Lipovetsky explica em A Felicidade Paradoxal, mediante os cruzamentos que aqui foram feitos, mostrou-se útil como chave hermenêutica deste campo religioso singular, proporcionando reflexões mais claras quanto às motivações para a prática consumista, bem como para a participação efetiva em grupos religiosos orientados pela teologia neopentecostal em seus mais variados estilos e desdobramentos, além também de descrever a maneira como estes grupos se organizam, bem como a natureza dos valores que promovem na sociedade. $\mathrm{O}$ "background" teórico e metodológico desenvolvido por Lipovetsky possibilita investigar o complexo e instigante campo religioso brasileiro dos neopentecostais.

Os discursos e as práticas religiosas neopentecostais se inserem num contexto sociohistórico marcado por crises e transformações. O nascimento do neopentecostalismo é concomitante às configurações das sociedades desenvolvidas atuais, delimitadas por Lipovetsky como hipermodernas.

É no interior das sociedades hipermodernas que se pode delimitar o neopentecostalismo a partir de suas características fundamentais: a Teologia do Domínio, a Teologia da Prosperidade, a eliminação dos estereotipados 
Religare, ISSN: 19826605, v.15, n.2, dezembro de 2018, p.451-482.

usos e costumes de santidade e sua organização empresarial. Essas características se constituem como campos de força a partir dos quais é forjada a antropologia neopentecostal. Ao sujeito que faz entrada no interior das igrejas neopentecostais é apresentado um ethos que estabelece as condições necessárias para seu processo de subjetivação.

Segundo os discursos religiosos neopentecostais o sujeito, quando vive o pacto ou sociedade com o próprio Deus, torna-se ilimitado e pode gozar a vida na experiência da mais pura realização e felicidade.

Lipovetsky (2004) sustenta que a sociedade dita pós-moderna perdeu a força de traduzir e exprimir o novo mundo que se anuncia, pois:

Hipercapitalismo, hiperclasse, hiperpotência, hiperterrorismo, hiperindividualismo, hipertexto - o que mais não é hiper? O que mais não expõe uma modernidade elevada à potência superlativa? Ao clima de epílogo segue-se uma sensação de fuga para adiante, de modernização desenfreada, feita de mercantilização proliferativa, de desregulamentação econômica, de ímpeto técnico-científico, cujos efeitos são tão carregados de perigos quanto de promessas (LIPOVETSKY, 2004, p. 53).

Para Lipovetsky, os comportamentos individuais também são regidos pela lógica do extremo:

[...] são prova o frenesi consumista, o doping, os esportes radicais, os assassinos em série, as bulimias e anorexias, a obesidade, as compulsões e vícios. Delineiam-se duas tendências contraditórias. De um lado, os indivíduos, mais do que nunca, cuidam do corpo, são fanáticos por higiene e saúde, obedecem às determinações médicas e sanitárias. De outro lado, proliferam as patologias individuais, o consumo anômico, a anarquia comportamental (LIPOVETSKY, 2004, p. $55)$.

A dinâmica do funcionamento individual, marcado pela lógica do extremo, é indicativa do princípio do paradoxo como possibilidade de compreensão das condições da subjetividade no mundo da hipermodernidade. O sujeito ilhado dos laços com o outro, que vive sob o 
Religare, ISSN: 19826605, v.15, n.2, dezembro de 2018, p.451-482.

primado da lógica do hiperindividualismo, oscila frequentemente, em seus comportamentos, de um princípio regulador de responsabilidade e operacionalidade para uma vivência de superação de limites. Esse processo é desvelador da superação das antigas formas de regulação social dos comportamentos. ${ }^{4}$

Na hipermodernidade, não há escolha, não há alternativa, senão evoluir, acelerar para não ser ultrapassado pela "evolução": o culto da modernização técnica prevaleceu sobre a glorificação dos fins e dos ideais. Quanto menos o futuro é previsível, mais ele precisa ser mutável, flexível, reativo, constantemente pronto a mudar, supermoderno, mais moderno que os modernos dos tempos heróicos (LIPOVETSKY, 2004, p. 57).

Nesta perspectiva que se pode evidenciar os alicerces que dão sustentação ao neopentecostalismo e à sua antropologia. ${ }^{5}$

\section{Pentecostalismos e Neopentecostalismos}

O campo religioso brasileiro sempre se apresentou como polissêmico, dado a muitas leituras e interpretações. Mais especificamente em se tratando do subcampo do Pentecostalismo, desde que este passou a ser um objeto de estudo dentro da academia, no final dos anos 60, início dos anos 70 do século XX, nada é mais verdadeiro. Depois de algumas décadas percebeu-se a necessidade de utilização de uma tipologia que demarcasse e facilitasse o acesso ao objeto em questão. Desde então, há um certo consenso entre os especialistas nesta área, de que a metáfora das "ondas marinhas", inicialmente utilizada no Brasil por Paul Freston seria uma boa ferramenta para a compreensão do movimento pentecostal brasileiro. Essa adaptação

4 PARAVIDINI, J. L. L.; GONÇALVES,M.A. Neopentecostalismo: desamparo e condição masoquista. Revista Mal estar e subjetividade, v. 9, n. 4, Fortaleza, dez-2009.

5 PARAVIDINI, J. L. L.; GONÇALVES,M.A. Neopentecostalismo: desamparo e condição masoquista. Revista Mal estar e subjetividade, v. 9, n. 4, Fortaleza, dez-2009. 
Religare, ISSN: 19826605, v.15, n.2, dezembro de 2018, p.451-482.

feita por Freston é fruto da apropriação da metáfora que David Martin utilizou para referir-se à história mundial do Protestantismo, na qual ele distingue três grandes ondas: a puritana, a metodista e a pentecostal (MARIANO, 1995, p. 28). A partir de um recorte histórico-institucional, a ideia inicialmente exposta por Paul Freston no Brasil - já que nos Estados Unidos tanto a metáfora marinha quanto o conceito neopentecostal já eram conhecidos - ganha novo fôlego com a utilização da expressão "neopentecostal", utilizada por inúmeros estudiosos do Pentecostalismo no Brasil, especificamente para se referir às igrejas da terceira onda, nascidas a partir da década de 1970, e que teriam como características básicas - apesar da falta de homogeneidade - posturas menos sectárias e ascéticas, uma postura mais liberal e tendências a investir em atividades extra-igreja, quando comparadas com suas antecessoras do Pentecostalismo clássico e do Deuteropentecostalismo. Para ser enquadrada como neopentecostal.

O conceito neopentecostal, desde então, virou expressão consagrada entre os estudiosos do fenômeno religioso pentecostal no Brasil. O trabalho em questão pretende discutir se esse conceito, a saber, neopentecostal, ainda é útil e serve para a compreensão dos grupos religiosos que estão presentes na arena religiosa nacional, e consequentemente vinculados ao movimento pentecostal denominado de terceira onda. Esse trabalho parte do pressuposto de que o conceito neopentecostal é hodiernamente um conceito-obstáculo que não consegue não dar conta da realidade religiosa pentecostal brasileira, sendo necessário ultrapassá-lo. A expressão conceito-obstáculo foi emprestada da obra do historiador brasileiro Ciro Flamarion Cardoso, quando este tratou da necessidade de se a construção do espaço mediante um diálogo com autores europeus.

Existem dois marcos históricos que inauguram o movimento pentecostal nos Estados Unidos, o primeiro em Topeka no estado do Kansas em 1901, liderado por Charles Fox Parham, porém devido à estranheza de sua 
Religare, ISSN: 19826605, v.15, n.2, dezembro de 2018, p.451-482.

doutrina, como uma tendência racista enfatizava a crença de que os anglosaxões descendiam das dez tribos de Israel perdidas na Assíria, além de acusações sobre sua orientação sexual, fizeram com que suas atribuições como precursor do pentecostalismo fosse deixadas de lado na historiografia do movimento. Apesar disso foi considerado "o pai do reavivamento pentecostal do século $X X^{\prime \prime}$, foi o primeiro a manifestar a experiência mística do "batismo no Espírito Santo", com experiências do fenômeno do transe e o fenômeno de falar em línguas estranhas que se tornaram marca dos pentecostais até os dias de hoje. Seria o reavivamento da crença no resgate das experiências místicas no período dos Apóstolos (DEMUNER, 2013, p. 1324).

O segundo marco histórico aconteceu na Azusa Street, em Los Angeles, no Estado da Califórnia, em 1906. Este movimento teve como líder um homem negro chamado William Joseph Seymour (1870-1922). O movimento liderado por Seymor foi marcado por manifestações como profecias divinas, milagres, curas e demais experiências espirituais. Esses acontecimentos chamaram a atenção da imprensa, contribuindo ainda mais para sua difusão. Uma característica importante desse movimento é que ele era formado por negros e imigrantes, ou seja, das camadas pobres da sociedade norte-americana, assim ganhou mais aceitação por parte dos fiéis, devido suas origens, muitos deles se tornam missionários e daí o movimento começa a ser difundido nos Estados Unidos e posteriormente no mundo.

O pentecostalismo rompeu as fronteiras dos Estados Unidos, sendo difundido pela Europa, Ásia, América Latina e África, até mesmo o catolicismo foi influenciado, surgindo dentro do mesmo o movimento de renovação carismática (1967). No Brasil ele chega pouco depois de seu surgimento nos EUA, em 1910. O pentecostalismo chegou por aqui com essas características, com alterações e adaptações realizadas ao longo do tempo. 
Religare, ISSN: 19826605, v.15, n.2, dezembro de 2018, p.451-482.

A primeira Igreja pentecostal a surgir no Brasil foi a Congregação Cristã em 1910, a segunda foi a Assembléia de Deus em 1911, ambas oriundas do movimento de Los Angeles e com características do movimento liderado por Seymor. No caso norte-americano, o movimento religioso foi uma resposta às igrejas protestantes que acabavam não abrigando as classes excluídas da sociedade (DEMUNER, 2013, p. 13-24, RODRIGUES,2002 ).

Alguns autores dividem o movimento em três etapas, primeira, segunda e terceira ondas do movimento pentecostal, ainda segundo Freston (apud MARIANO, 1993, p. 28-29):

[...] O pentecostalismo brasileiro pode ser compreendido como a história de três ondas de implantação de igrejas. A primeira onda é a década de 1910, com a chegada da congregação Cristã (1910) e da Assembléia de Deus (1911) (...) A segunda onda pentecostal é dos anos 50 e início de 60, na qual o campo pentecostal se fragmenta, a relação com a sociedade se dinamiza e três grandes grupos (em meio a dezenas de menores) surgem: a Quadrangular (1951), Brasil para Cristo (1955) e Deus é Amor (1952). O contexto dessa pulverização é paulista. A terceira onda começa no final dos anos 70 e ganha força nos anos 80. Suas principais representantes são a Igreja Universal do Reino de Deus (1977) e a Internacional da Graça de Deus (1980) (...) O contexto é fundamentalmente carioca.

Já outros autores classificam como, pentecostalismo clássico, deuteropentecostalismo e neopentecostalismo. Mariano (2012, p. 32) traça a distinção da primeira e segunda vertente pentecostal pelas questões evangelísticas. Como mudanças na doutrina podemos indicar o abandono dos chamados usos e costumes, que são, por exemplo, as roupas, estilos musicais, porém, com o mesmo núcleo teológico. Para diferenciá-las foi utilizado o radical deutero que significa segundo ou segunda vez. Já o neopentecostalismo surgiu em meados da década de 70 (século XX), com a criação da Igreja Universal do Reino de Deus (1977). 
Religare, ISSN: 19826605, v.15, n.2, dezembro de 2018, p.451-482.

Começou a surgir um novo tipo de igreja evangélica, inédito no Brasil, sendo suas mais conhecidas representantes a Igreja Universal do Reino de Deus, a Igreja Internacional da Graça de Deus, ou a Renascer em Cristo. Em menos de três décadas, essas igrejas conheceram um crescimento avassalador, diversificando suas atividades e práticas a ponto de definir um perfil próprio do campo religioso evangélico, onde configuram o que veio a ser chamado de neopentecostalismo. Todavia, apesar de suas diferenças significativas, o que aproxima essas igrejas é o mesmo uso extensivo e agressivo que fazem dos meios de comunicação (MONTES, 1998, p. 85-87, RODRIGUES, 1999).

Os eventos em estádios de futebol ou em grandes espaços públicos abertos têm multiplicado sua presença nos grandes centros urbanos por todo país. O neopentecostalismo é um fenômeno preliminarmente urbano, envolvendo a população em suas pregações e campanhas. Em alguns casos, elas chegaram mesmo a inovar, com organização de eventos festivos constituído por verdadeiras multidões. As aquisições comerciais passaram a ser evidentes e notórias, como no caso da Igreja Universal com a compra sistemática de edificações de porte em lugares públicos de visibilidade, como cinemas, teatros, supermercados e galpões, como também a aquisição de uma atual emissora de televisão (MONTES, 1998, p. 86, RODRIGUES, 1999).

O neopentecostalismo desponta como a "terceira onda" dos movimentos protestantes e mostra alguns aspectos importantes. "Onda" que tem uma presença no "mundo" mais efetiva. Na realidade, o aumento dos evangélicos que lhes deu visibilidade se refletiu no interior do próprio grupo na década de 80 (Século XX), marcando a sua presença na cena política. O grupo passou a formar a chamada bancada evangélica do Congresso nacional durante a Assembleia Nacional Constituinte.

Tudo é novo no panorama religioso brasileiro, ou pelo menos assim parece. A fé católica no Brasil, graças à sua Igreja apostólica e romana, sempre procurou garantir sua projeção na vida pública, social e política, por meios 
Religare, ISSN: 19826605, v.15, n.2, dezembro de 2018, p.451-482.

menos diretos, mais elitistas talvez, já que dependentes da relação privilegiada da hierarquia eclesiástica com o Estado e os governantes, ou então de uma cumplicidade mais ou menos declarada, fundada no compartilhar de objetivos sociais e políticos comuns com as classes dirigentes da vida social e política do país. Mesmo ao firmar declaradamente sua presença na vida pública, nos duros anos do regime militar, a Igreja falou aos governantes de modo direto mas de igual para igual, na altaneira distância de quem, mudando de rumo, sabe que as suas bases de poder estão em outra parte, no seio do povo, ainda que este fosse apenas o povo visto do altar na vívida expressão de um analista. A participação de seus fiéis na vida pública por meio da representação política jamais resultou numa ação coordenada nos moldes desenvolvidos pela bancada evangélica. Nem seus sacerdotes, à exceção talvez dos tempos coloniais e do Império, engajaram-se tão direta e publicamente na disputa política, pleiteando cargos eletivos.

A formação de seus quadros especializados, longa e dispendiosa, arrisca-se a todo instante a sofrer solução de continuidade em face da ameaça sempre presente da crise das vocações. Seu poder econômico, certamente um verdadeiro império, nunca foi alardeado de forma aberta e com orgulho. Talvez o que espante, ou pareça novo, e mesmo chegue a chocar, é ver através do outro - uma religião minoritária - aquilo que nos envolve de tão perto e desde sempre que acabou por se tornar invisível. Talvez tudo resulte apenas de uma diferença de estilo, mais contido e eivado de meandros e mediações - maquiavelicamente dissimulado, como talvez alguém dissesse? -, num caso, mais agressivamente declarado, noutro. A ética de Inácio de Loyola ali, a de Lutero e Calvino, aqui. Dois estilos da ação privada marcando diferentes instituições religiosas, a do contato face a face, íntimo e pessoal, e a da iniciativa privada (MONTES, 1998, p. 89-91).

Os perfis socioeconômico e demográfico de pentecostais e protestantes são bastante distintos. Dados do último Censo revelam que a maioria dos 
Religare, ISSN: 19826605, v.15, n.2, dezembro de 2018, p.451-482.

pentecostais apresenta renda e escolaridade inferiores à média da população brasileira. Grande parte deles recebe até três salários mínimos e ocupa empregos domésticos, em geral modestos e precários, numa proporção bastante acima da média nacional. Já protestantes históricos apresentam renda e escolaridade mais altas, ambas bem superiores à média brasileira, estando distribuídos mais nos níveis escolares de segundo grau, graduação e pós-graduação e nas faixas de renda entre seis e vinte salários mínimos. Pentecostais e protestantes são urbanos e apresentam maior proporção de mulheres que de homens. Quanto à origem étnica dos fiéis, os primeiros sobressaem pela presença de pretos e pardos superior à média da população, enquanto os últimos pela maior proporção de brancos. Os pentecostais abrigam mais crianças e adolescentes do que adultos, enquanto os protestantes mais adultos e idosos (MARIANO, 2004).

Sem perder necessariamente sua distintividade religiosa, as igrejas neopentecostais revelam-se, entre as pentecostais, as mais inclinadas a acomodarem-se à sociedade abrangente e a seus valores, interesses e práticas. Daí seus cultos basearem-se na oferta especializada de serviços mágicoreligiosos, de cunho terapêutico e taumatúrgico, centrados em promessas de concessão divina de prosperidade material, cura física e emocional e de resolução de problemas familiares, afetivos, amorosos e de sociabilidade. Oferta sob medida para atender a demandas de quem crê que pode se dar bem nesta vida e neste mundo recorrendo a instituições intermediárias de forças sobrenaturais. Com tal estratégia, empregada também nos evangelismos pessoal e eletrônico, atraem e convertem majoritariamente indivíduos dos estratos pobres da população, muitos deles carentes e em crise pessoal, geralmente mais vulneráveis a esse tipo de prédica. Não obstante o apelo sistemático à oferta de soluções mágicas configure uma prática usual nas religiões populares no Brasil, observa-se que, no caso neo-pentecostal, tal procedimento, diferentemente do que ocorre no catolicismo popular, por 
Religare, ISSN: 19826605, v.15, n.2, dezembro de 2018, p.451-482.

exemplo, é orquestrado pelas lideranças eclesiásticas e posto em ação nos cultos oficiais e por meio do evangelismo eletrônico (MARIANO, 2004, p. 124).

As igrejas evangélicas não contam com uma organização institucional protegida das querelas internas. Há autonomia, pois acada uma se projeta em seus espaços e nas suas comunidades locais com influências na sociedade civil. Quanto ao neopentecostalismo, tem características significativas em sua estrutura. Herdaram no aspecto teológico de sua matriz, a pneumatologia, soterologia e a escatologia, com o complemento marcante da chamada Teologia da Prosperidade (BURJACK, 2013, p. 95, RODRIGUES, 2016).

O evangelismo brasileiro apresenta características marcantes. Entre estas últimas está o gosto por novidades. Líderes e fiéis sentem que, para manter o interesse pelas coisas de Deus, é preciso que de tempos em tempos surja um ensino novo, uma nova ênfase ou experiência. Geralmente tais inovações têm sua origem nos Estados Unidos. Assim como outros países, o Brasil é um importador e consumidor de bens materiais e culturais norteamericanos. Isso ocorre também na área religiosa. Um movimento de origem americana que tem tido enorme receptividade no meio evangélico brasileiro desde os anos 80 é a chamada teologia da prosperidade (MATOS, 2008).

Ao contrário do que muitos imaginam, as idéias básicas da confissão positiva não surgiram no pentecostalismo. Todavia, por causa de algumas afinidades com a cosmovisão pentecostal, como a crença em profecias, revelações e visões, foi em círculos pentecostais e carismáticos que a confissão positiva teve maior acolhida, tanto nos Estados Unidos como no Brasil. A história de seus dois grandes pioneiros irá elucidar as raízes dessa teologia popular. Embora os adeptos da teologia da prosperidade considerem Kenneth Hagin o pai desse movimento, pesquisas feitas por vários estudiosos, como D. R. McConnell, demonstraram conclusivamente que o verdadeiro originador da confissão positiva foi Essek William Kenyon (1867- 
Religare, ISSN: 19826605, v.15, n.2, dezembro de 2018, p.451-482.

1948). Esse evangelista de origem metodista nasceu no condado de Saratoga, Estado de Nova York, e se converteu na adolescência. Em 1892 mudou-se para Boston, onde estudou no Emerson College, conhecido por ser um centro do chamado movimento "transcendental" ou "metafísico".

Em 1934, Hagin começou seu ministério como pregador batista e três anos depois se associou aos pentecostais. No mesmo ano foi licenciado como pastor das Assembléias de Deus e pastoreou várias igrejas no Texas. Em 1949 começou a envolver-se com pregadores independentes de cura divina e em 1962 fundou seu próprio ministério. Finalmente, em 1966 fez da cidade de Tulsa, em Oklahoma, a sede de suas atividades. Ao longo dos anos, o Seminário Radiofônico da Fé, a Escola Bíblica por Correspondência Rhema, o Centro de Treinamento Bíblico Rhema e a revista "Word of Faith" (Palavra da Fé) alcançaram um imenso número de pessoas.

Os ensinos de Hagin influenciaram um grande número de pregadores norte-americanos, a começar de Kenneth Copeland, seu herdeiro presuntivo. Outros seguidores seus foram Benny Hinn, Frederick Price, John Avanzini, Robert Tilton, Marilyn Hickey, Charles Capps, Hobart Freeman, Jerry Savelle e Paul (David) Yonggi Cho, entre outros. Em 1979, Doyle Harrison, genro de Hagin, fundou a Convenção Internacional de Igrejas e Ministros da Fé, uma virtual denominação (MATOS, 2008).

Nos anos 80, os ensinos da confissão positiva e do evangelho da prosperidade chegaram ao Brasil. Um dos pioneiros foi o pastor Rex Humbard. Marilyn Hickey, John Avanzi. Entre as primeiras manifestações do movimento estavam a Igreja do Verbo da Vida e o Seminário Verbo da Vida (Guarulhos), a Comunidade Rema (Morro Grande) e a Igreja Verbo Vivo (Belo Horizonte). Alguns líderes que abraçaram essa teologia foram Jorge Tadeu, das Igrejas Maná (Portugal); Cássio Colombo, do Ministério Cristo Salva, em São Paulo; o "apóstolo" Miguel Ângelo da Silva Ferreira, da Igreja Evangélica Cristo Vive, no Rio de 
Religare, ISSN: 19826605, v.15, n.2, dezembro de 2018, p.451-482.

Janeiro, e R. R. Soares, responsável pela publicação da maior parte dos livros de Hagin na sociedade brasileira.

O significado de teologia da prosperidade é muito amplo e complexo. Na verdade essa tendência surge no Brasil durante uma crise econômica na qual as taxas do desemprego encontravam-se muito altas. Nesse contexto social de pobreza, violência, desestruturação familiar, ineficácia dos serviços públicos de educação e saúde, a população procura por "bênçãos" materiais e por resoluções de diversos problemas (FILIPE, 2011, p. 11-18). Embora, o fenômeno neopentecostal também atinja classes sociais médias e abastadas. Mas é, sobretudo por intermédio da mídia que o poder dessa nova presença evangélica se faz sentir penetrando na intimidade das casas a cada noite, graças à programação radiofônica e televisiva especializada que preenche os horários noturnos de grande parte das emissoras com a difusão de sessões de culto, clipe musicais e mensagens religiosas, como também, as pregações na internet. Para os defensores da Teologia da Prosperidade, o desígnio de Deus é estabelecer um pacto ou sociedade com aqueles que lhes são fiéis. Se o pecado de Adão e Eva quebrou a aliança existente entre Deus e o ser humano, é através do sacrifício de Jesus Cristo na cruz que esta sociedade é refeita. Assim, Jesus Cristo vem a ser o caminho de volta a Deus. Através do seu sacrifício, Ele removeu para sempre a nossa condenação e derrubou as barreiras que estavam entre nós e Deus. O fiel, em busca da sustentação de sua responsabilidade no contrato de sociedade com Deus, deve conduzir-se moralmente de acordo com as exigências bíblicas e, de modo especial, é chamado a acolher e viver um compromisso financeiro celebrado através do dízimo e das ofertas.

Para a inauguração de uma nova identidade, o fiel manifesta uma permanente preocupação em não se deixar levar pelas seduções do diabo, que teima em levá-lo ao pecado. É na fé que o fiel diz encontrar força para transformar-se vivendo de acordo com as prescrições ético-morais da Bíblia e 
Religare, ISSN: 19826605, v.15, n.2, dezembro de 2018, p.451-482.

dos discursos dos líderes religiosos. A fé teria a força de produzir as transformações onde o ser humano não consegue chegar confiando exclusivamente em si mesmo.

A fé é tudo isso e mais ainda. Ela transforma o ambiente, qualquer que seja ele, por mais tenso e tenebroso que possa parecer, a fé o limpa e o purifica; o que os médicos não podem fazer, o que os remédios não podem realizar, a fé faz e realiza.

De acordo com os discursos religiosos neopentecostais, se o fiel ainda não usufruiu da obtenção das graças que almeja é porque ele ainda não trilhou os caminhos da fé. Sua trajetória existencial ainda não foi delimitada em conformidade com a fé e sua comunhão com Deus também não se estreitou a ponto de se tornar possível firmar a assinatura desse contrato.

No entanto, a lógica que rege a montagem desse contrato preconiza uma condição existencial inatingível para a vida do fiel. Neste sentido, o sujeito jamais poderá assinar esse contrato, posto que a afirmação de sua identidade é pressuposta pelas marcas de sua condição faltante.

Porém, a parceria com Deus pressupõe um preço a ser pago. É com base nessa ideia que Macedo assim afirma enfaticamnete: "Tudo que é valioso tem um preço. Para conseguir a medida suficiente de fé a ponto de transportar montanhas, também devemos esperar o preço que precisamos pagar por isso" (MACEDO, 2005, p. 24).

O casamento entre a terceira onda do pentecostalismo e a teologia da prosperidade rendeu frutos variados com o surgimento de inúmeras igrejas. Vejamos algumas destas igrejas e as suas trajetórias históricas:

\section{Igreja de Nova Vida}

A Igreja Nova vida é inserida aqui dentre as igrejas neopentecostais, apesar de ser caracterizada como do deuteropentecostalismo, por ser a célula 
Religare, ISSN: 19826605, v.15, n.2, dezembro de 2018, p.451-482.

embrionária do neopentecostalismo. A Nova Vida foi fundada em 1960 no Rio de Janeiro, no bairro de Bota Fogo, seu fundador foi o missionário canadense Robert McAlister (1931-1993) ou bispo Roberto como ficou conhecido no Brasil, desde seu início a Igreja de Nova Vida se propôs a alcançar a classe média, coisa que não era comum no pentecostalismo que surgiu das camadas desfavorecidas da sociedade, num trecho da obra escrita por seu filho, Walter McAlister, Neopentecostalismo a História não contada, faz os seguintes apontamentos (MCALISTER, 2012, p. 40-41) Como vemos a Igreja Nova Vida foi projetada para alcançar a classe média, e porque não dizer média alta, pela sua localização na Zona Sul, Mariano (2010, p. 53) destaca que talvez esse possa ter sido o motivo de seu crescimento não tão expressivo como foi no caso da Universal do Reino de Deus, cujo seu fundador, Edir Macedo, foi membro da Nova Vida e adotou varias práticas que aprendeu com Mc Alister. A Nova Vida surgiu de um programa de rádio chamado "A Voz de Nova Vida", onde o seu fundador fazia suas pregações, a ênfase dessa igreja era no exorcismo e na cura divina, Mc Alister chegou a publicar dois livros tratando do assunto, Mãe de Santo em 1968 e Crentes endemoniados: a nova heresia em 1975, o primeiro seria a origem da perseguição as religiões afro-brasileiras que Edir Macedo iria implementar na Igreja Universal.

Ele também organizou muitos encontros no Maracãnazinho. Um dos mais impressionantes foi marcado para o dia que acabou sendo o dia do golpe militar 1964. Todas as reuniões públicas tinham sido proibidas. O Jovem Pastor Roberto recebeu uma visita do assessor de um dos oficiais de Estado. Pensava ser o fim do evento. Mas, ao invés de cancelar o culto, o político tinha mandado alguém para pedir que reservasse um lugar para ele. Naquele dia, meu pai pregou como poucas vezes tinha pregado. Orou pelos enfermos e cantou enquanto os tanques do exército passavam pela porta do estádio (MCALISTER, 2012, p. 149). 
Religare, ISSN: 19826605, v.15, n.2, dezembro de 2018, p.451-482.

\section{Igreja Internacional da Graça de Deus}

Foi fundada em 1980, após o desentendimento de seu fundador Romildo Ribeiro Soares com Edir Macedo, ambos fundadores da Igreja Universal do Reino de Deus. R. R. Soares como ficou conhecido, Nasceu na cidade de Muniz Freire, Espírito Santo, passou por varias denominações, foi da Igreja Presbiteriana, Batista, e em 1968 foi membro da Igreja Nova Vida, depois que saiu da Nova Vida foi pastor na Casa da Benção e participou também da Cruzada Caminho eterno, e em 1977 fundou a Universal d Reino de Deus, porém permaneceu na mesma somente por três anos. R.R. Soares chegou a tentar a carreira política em 1990, porém não obteve sucesso. Ele se destacou como um excelente apresentador de televangelismo lançou vários livros e inclusive é proprietário de uma editora, a graça editorial. Sarquetto (2007, p. 36) diz que em 1998 a Igreja Internacional da Graça de Deus já contava com 317 templos, sucesso certamente alcançado devido às características proselitistas de seu líder e também a utilização dos meios de comunicação em massa, como TV e rádio (DEMUNER, 2013, p. 20).

\section{Sara Nossa Terra}

Fundada em 1976 na cidade de Goiânia em São Paulo por um professor de física e empresário da Editora Koinonia, Robson Lemos Rodovalho. Seu fundador tem origens no Kardecismo e na umbanda, após sofrer um acidente aos 14 anos ele se converte na Igreja Presbiteriana do Brasil. Adepto do movimento Mocidade para Cristo foi alicerçando as bases para criação de sua igreja, neste grupo ele recebe o chamado batismo no Espírito Santo, que é uma característica em todas as Igrejas pentecostais. Rodovalho torna-se pastor em 1976 na igreja até então chamada Comunidade Evangélica, e em 1992 essa 
Religare, ISSN: 19826605, v.15, n.2, dezembro de 2018, p.451-482.

passa a se chamar Sara Nossa Terra. Em 1997 é adotado o sistema de governo eclesiástico episcopal, onde o poder é centralizado na figura do bispo.

Em seus primeiros anos o crescimento foi lento, porém quando passada duas décadas de existência a igreja passou a contar com mais de 200 filiais, também expandindo as mesmas para fora do país. Devido esse crescimento, houve reforma em sua administração em 1994, resultando em alguns desligamentos de pastores que não aceitaram as reformas. Não somente o poder é centralizado, como também sua administração, os recolhimentos de ofertas e dízimos são destinados a uma central, que redistribui as verbas conforme as necessidades das igrejas. Assim como outras denominações neopentecostais, a igreja Sara Nossa Terra, promove a ênfase em seus cultos a musica gospel, atraindo uma membresia jovem, além de ter o projeto Atletas para Cristo, que atrai atletas e amantes de esportes para seus templos (SAQUETTO, 2007, p. 40-41).

\section{Igreja Renascer em Cristo}

Teve como fundadores, o casal, Estevam Hernandes e Sônia Hernandes. Surgiu em São Paulo no ano de 1986, seus fundadores: Estevam é ex-gerente da empresa Xerox do Brasil e da Itautec e Sônia era exproprietária de uma "boutique". A Igreja começou em uma pizzaria, depois passaram a se reunir na sede Igreja Evangélica Árabe, no bairro do Paraíso. Em 1989, alugaram onde funcionava um cinema, o Cine Riviera, e esse se tornou sua sede. A Igreja Renascer em Cristo, assim como outras neopentecostais, alcançou um crescimento gigantesco, pois em 1998, já contavam com 300 templos e filias na França, Portugal, Uruguai e Estados Unidos. Assim como a Nova Vida, adota o sistema de governo eclesiástico episcopal, que centraliza o poder na figura do bispo. Logo depois de ter se 
Religare, ISSN: 19826605, v.15, n.2, dezembro de 2018, p.451-482.

tornado bispo em 1994, Estevam é consagrado apóstolo e reconhecido pela Conferencia profética da Renascer.

A Igreja Renascer obtém um patrimônio riquíssimo, pois são proprietários de rádios, emissoras de TV UHF, editora, produtora musical, do jornal Gospel News, do Instituto Renascer de Ensino, do Cartão Gospel Bradesco Visa, da livraria Point Gospel, da gravadora Gospel Records e tem sob seu domínio a marca Gospel no Brasil. A Renascer promove megaeventos liderando o movimento gospel no Brasil. A característica mais marcante da Renascer é a musica gospel, que é utilizada para atrair seus fiéis, os ritmos são os mais variados possíveis, como rap, rock, funk e outros. Isso fez com essa igreja atraísse muitos jovens e também membros de igrejas com uma doutrina mais rígida, por exemplo, aquelas do pentecostalismo clássico. A igreja conta também com muitos membros empresários e para isso criou a Associação Renascer de Empresários e Profissionais Evangélicos (DEMUNER, 2013, p. 20-21).

\section{Estudo de caso: A Igreja Bola de Neve em Vila Velha, Espirito Santo}

Da terceira "onda" do pentecostalismo, temos a Bola de Neve. Conhecida por seu perfil moderno e inovador, a Bola de Neve Church (BDN), começou sua história no ano de 1999, após seus fundadores se desligarem da conhecida Igreja Renascer em Cristo. A partir de então, a igreja passou a crescer constantemente, chamando a atenção e atraindo fiéis, assim como estudiosos do novo cenário religioso constituído. Fundada pelo apóstolo e surfista Rinaldo Luiz de Seixas Pereira, a Igreja Evangélica Bola de Neve em menos de uma década conquistou prestígio e notoriedade, tornando-se um empreendimento religioso visitado a cada culto por inúmeros jovens, atraídos

pela publicidade que anuncia a igreja como a grande novidade do mercado 
Religare, ISSN: 19826605, v.15, n.2, dezembro de 2018, p.451-482.

de bens da salvação. Seu fundador e idealizador anteviu a necessidade de criar um "produto" diferenciado para atingir um público específico, acompanhando, desse modo, a tendência de especialização, diferenciação e segmentação das organizações evangélicas. No mercado totalmente saturado, o pastor Rina, como é conhecido, teve a iniciativa de escolher um segmento pouco prestigiado e explorado pelas igrejas evangélicas (DANTAS, 2010, p. 53-80).

A fim de atrair surfistas, skatistas, fisiculturistas, lutadores e esportistas de uma forma geral, a Igreja Bola de Neve lançou um tipo de "produto" religioso que associa cuidado com a saúde, corpo sarado, imagem descolada com linguagem informal, inclusive com a utilização de "gírias" nos cultos.

Os membros que dela fazem parte possuem visual despojado, usam tatuagens e "piercings", vestem roupas descontraídas que valorizam os contornos do corpo, aderem a acessórios da moda, pertencem a diferentes "tribos". A maioria dos eventos de evangelização desta igreja, assim como os campeonatos esportivos organizados por ela, ocorrem na praia.

O templo é decorado com artefatos praianos para reproduzir o ambiente litorâneo. Espalhadas pela igreja há barracas de praia, pranchas de surfe e fotos de surfistas fazendo manobras. No altar, há uma pranchapúlpito, o que se tornou a marca da congregação e favoreceu sua divulgação no mercado da fé, seu mito fundante. (MARANHÃO, 2013, p.77). A imagem da nova organização evangélica, que agrega esporte, corpo e religião, teve um efeito publicitário gigantesco, estimulando a adesão de muitos jovens. O nome da igreja revela e anuncia as pretensões de seu fundador: crescer de forma progressiva e ininterrupta como uma bola de neve (DANTAS, 2010).

O sucesso da igreja se deve à identificação do jovem com sua imagem, à proximidade dos pastores, à informalidade dos cultos e à linguagem descontraída e coloquial. A Igreja Bola de Neve foi progressivamente 
Religare, ISSN: 19826605, v.15, n.2, dezembro de 2018, p.451-482.

construindo a sua imagem como aquela que "rompe" com tradicionalismos, principalmente no que diz respeito às roupas e aos estilos da moda. A preocupação com a saúde e a presença em grande quantidade de jovens são suas marcas características (DANTAS, 2010, p. 53-80).

A utilização das "gírias" também é um dado significativo nos cultos e eventos da Igreja Bola de Neve. Em uma pesquisa realizada nas redes sociais, foi possível coletar algumas delas: "Brother", culto "iradíssimo", música "chistafari", Deus muito "top", gírias do surf, entre outras. As roupas de seus integrantes são bermudas, blusas da moda, jeans modernos, entre outras roupas que nada lembram as vestimentas tradicionais dos protestantes, tanto homens quanto mulheres. ${ }^{6}$

A experiência religiosa nas igrejas evangélicas voltadas para classes médias e altas acompanham o movimento da Hipermodernidade em que as pessoas buscam o consumo das sensações, mesmo que sejam as sensações ditas espirituais. Gilles Lipovetsky nos diz que as pessoas amam o consumo para aliviarem o peso da vida. Há uma estetização do mundo, estetização do consumo e da própria vida.

Quando há uma igreja em que seu ícone é uma prancha de surf ou uma bicicleta (Igrejas Bola de Neve na Bahia), que nos remete a uma eterna juventude tão cobiçada desde os tempos das lendas medievais, igreja constituída por jovens que representam o público-alvo em sua maioria, é perceptível que o hedonismo da "segunda revolução do individualismo" segundo Lipovetsky está em evidência. Com cultos que demonstram a força vibrante da juventude, o pentecostalismo da novidade de igrejas com patente corte de classe (média e alta), demonstram que consumir tanto bens materiais quanto bens "espirituais" fazem parte do prazer hipermoderno que busca o excêntrico.

6 Disponível em: <https://www.youtube.com/channel/UCqjimrVF91RBCmYc9u61wGg $\geq$. Acesso em: 06 de set. de 2018. 
Religare, ISSN: 19826605, v.15, n.2, dezembro de 2018, p.451-482.

O culto "boite" faz parte da vida devocional de sua membresia. Luzes, brilho e gelo seco nas celebrações, embaladas pelo "gospel" e ritmos dançantes, fazem parte destas reuniões. Tempos atrás, a Igreja Católica realizava festas luxuosas e ostentatórias. A romanização reprimiu o catolicismo rústico que assumiu um perfil "puritano". O neopentecostalismo de viéis empresarial captou este nicho de mercado. Cultos que lembram "baladas" e "rolês" joviais tomam conta de algumas igrejas neopentecostais, ou do pentecostalismo da novidade.

Vila Velha é um município da microrregião de Vitória no estado do Espírito Santo que apresenta trinta e dois quilômetros de litoral, sendo praticamente todo recortado por praias as quais constituem importantes símbolos turísticos e paisagísticos, como a Praia da Costa, Itaparica e Itapoã. ${ }^{7}$

O Ministério Bola de Neve está a quase dez anos estabelecido em Vila Velha. O Ministério possui outras duas igrejas no estado em Ponta da Fruta e também Cachoeiro de Itapemirim. Além das igrejas, há trabalhos missionários na Serra, Guarapari, Nova Venécia e Santa Teresa. Recentemente, A Bola de Neve abriu um templo em Vitória (capital), na Praia do Canto.

A Igreja Bola de Neve em Vila Velha situa-se em Coqueiral de Itaparica, bem próxima da praia, reiterando o modelo da Bola de Neve do Rio De Janeiro, cuja igreja situa-se na Barra da Tijuca, litoral carioca. A Igreja Bola de Neve, por atrair os jovens em sua maioria, desenvolve uma "liturgia bronzeada" com seus membros providos de estilos descolados e corpos malhados.

A primeira vez no templo da Bola de Neve (Vila Velha), logo na entrada, a saudação é "prosperidade" com um abraço. O culto é longo ( dura cerca de duas horas e meia), provido de uma etapa de louvor com danças dos

${ }^{7}$ Disponível em <www.vilavelha.es.gov.br)>. Acesso em 01 de set. de 2018. 
Religare, ISSN: 19826605, v.15, n.2, dezembro de 2018, p.451-482.

membros e visitantes. Algumas pessoas chegam a ir para frente da igreja, bem próximas do púlpito, e dançam freneticamente no meio de um jogo de luzes.

As mensagens dos pastores e pastoras são mensagens faladas em um tom informal (Com a utilização de gírias constantemente), como também, com gritos motivacionais em determinadas partes do desenrolar do culto ${ }^{8}$ Visualiza-se também, no espaço religioso neopentecostal, um discurso e uma prática recorrentes carregados de um tom triunfalista relacionado a conversão e a conservação de novos membros. A estratégia a ser adotada para conquista e manutenção de novos membros é a fragmentação da igreja em pequenos núcleos que deverão ser multiplicados. Este pequeno grupo é denominado por célula. Elas estão localizadas nas casas e é a partir delas que a captação de novos membros ou associados ocorre com o surgimento das lideranças.obedecendo a uma lógica semelhante ao "marketing" de rede. A Bola de Neve também adota a prática das células, inclusive, há um estímulo dos dirigentes intensamente para criação e propagação desta modalidade de “fidelização" do "cliente".

A concepção do modelo de igreja em células surgiu do imaginário de um pastor assembleiano, David Yonggi Cho. Figura emblemática para o movimento de igrejas em células. A ideia de ter as igrejas no formato das células surgiu na mente do pastor Cho no período em que ele se recuperava de uma doença. Ele apresenta a célula como a menor igreja do mundo, um lugar onde o ser humano consegue receber o devido valor que é merecido.

Cho afirmava que a célula é o ambiente necessário para desenvolvimento e assimilação doutrinária. Na sua concepção, é neste ambiente da célula que o cristão tem a possibilidade de participar ativamente na vida da igreja em seu cotidiano (BURJACK, 2013, p. 94-95).

${ }^{8}$ Coleta de impressões sobre o culto da Igreja evangélica Bola de Neve em Vila Velha (ES), ano 2015. 
Religare, ISSN: 19826605, v.15, n.2, dezembro de 2018, p.451-482.

Sobre a conexão Bola de Neve e mercado, temos o livro A grande onda vai te pegar, de Eduardo Meinberg, que foi censurado pela Igreja Bola de Neve ao ser lançado em 2013. Logo em seu primeiro capítulo, intitulado "Marketing de guerra santa - em trânsito", se inicia tratando dos famosos, artistas e celebridades que já fizeram parte ou participam da Bola de Neve,na qual se envolvem desde atores até lutadores famosos e ex-atrizes. Eduardo Meinberg enfoca como é constituído o ambiente da igreja, questionando em alguns momentos se a participação dessas celebridades faz parte da estratégia de marketing arquitetada ou se seria mero acaso. Em seguida, o autor discorre acerca dos métodos em que se baseia o "marketing" da igreja, referindo-se a este como marketing de guerra santa, termo adaptado do conceito de "marketing de guerra" (de Al Ries e Jack Trout) para o mercado religioso, devido à criação, apropriação e ressignificação de estratégias de gerenciamento militar e/ou empresarial, efetuadas pelas agências religiosas. Tal conceito nos permite compreender como a Bola de Neve realiza sua atuação diferencial baseada na midiatização do discurso e na espetacularização da fé utilizando como meio de articulação o ciberespaço para divulgação de suas "mercadorias e ofertas". O autor trata da identidade própria da igreja, comentando a respeito da organização interna, hierárquica, a manutenção por meio de ministérios, divisão das células e como seu "marketing" da guerra santa se efetua.

É tratada a questão do comércio no interior da agência, sua mercantilização, o uso de canções e o indevido uso do termo música gospel.

O autor mostra como a igreja se estrutura no espaço virtual, utilizando a internet como espaço de difusão da doutrina, da instituição e até mesmo de mercadorias.

A temática do livro funciona como uma porta de entrada para maiores reflexões, em um exercício de compreensão a respeito do papel das igrejas evangélicas na atualidade. As novas instituições religiosas buscam atender 
Religare, ISSN: 19826605, v.15, n.2, dezembro de 2018, p.451-482.

aos desejos reais das pessoas, em um plano terreno e material, modelando-se e se apropriando de elementos próprios do tempo em que estão inseridas, carregando suas origens, porém em constante transformação, assim como são também um reflexo da realidade e das atuais demandas subjetivas e coletivas que envolvem um novo perfil do fiel. Diz o autor:

A "identidade" da BDN é caracterizada pela aparente ambiguidade entre um discurso derretido, flexível em relação a usos e costumes, e um congelado, marcado pelo fundamentalismo, e refletida nos diferentes policiamentos em relação à sexualidade, afetividade e papéis de gênero, nas apropriações e significações em relação ao corpo e ao esporte e no uso das teologias de domínio, cura/libertação, saúde perfeita, prosperidade e batalha espiritual (MARANHÃO, 2013, p. 69).

O livro trata, assim, das transformações e ressignificações que vêm ocorrendo no âmbito religioso nas últimas décadas, um estudo de caso relativo à constituição e gerenciamento de mercado religioso de bens da salvação no tempo presente. Com ênfase no âmbito mercadológico a que estão incorporadas as novas agências religiosas, propõe elaborar um estudo reflexivo acerca da forma como é realizado o marketing da guerra santa, o espetáculo e ciberespaço para atração de fiéis (FERREIRA, 2014, p. 270-276).

Já dizia o perspicaz e lúcido Jean Baudrillard:

Disney vence ainda em outro plano. Não satisfeito de apagar o real transformando-o numaimagem virtual em três dimensões, mas sem profundidade, apaga o tempo sincronizando todas as épocas, todas as culturas, no mesmo travelling, justapondo-os no mesmo cenário. Inaugura assim o tempo real, pontual unidimensional, ele próprio sem profundidade: nem presente, nem passado, ne futuro, mas sincronia imediata de todos os lugares, de todos os tempos, na mesma virtualidade intemporal. Lapso ou colapso do tempo: é isso precisamente a quarta dimensão. Aquela do virtual, do tempo real que, longe de juntar-se às três dimensões do espaço real, as apaga...Disney realiza de facto essa utopia intemporal, produzindo todos os acontecimentos passados ou futuros, em telas simultâneas, mixando inexoravelmente todas as sequencias - como apareceriam ou 
Religare, ISSN: 19826605, v.15, n.2, dezembro de 2018, p.451-482.

aparecerão para outra civilização que não a nossa. Mas já é a nossa. Pois já nos é cada vez mais difícil imaginar o real, imaginar a História, a profundidade do tempo, o espaço em três dimensões - tão difícil quanto era outrora, a partir do mundo real, imaginar o universo virtual ou a quarta dimensão (BAUDRILLARD, 2002, p. 108-109).

Este artigo é fruto de uma cuidadosa pesquisa de campo e também teórica sobre igrejas neopentecostais brasileiras em andamento na Universidade Federal do Espírito Santo (UFES). Concluindo a análise deste fenômeno religioso, em Vila Velha (ES), a Bola de Neve reitera seu modelo de conversão com muita luz, purpurina e redes sociais (Ciberespaço). Cultos "iradíssimos" de um Jesus que é "top", quase um super-herói para uma juventude que se encontra na transição para um "mundo adulto" áspero e com perspectivas indefinidas. Cultos com muitos estilos do "gospel" reunindo jovens descolados durante algumas horas à beira-mar. A membresia jovial canta e dança para Deus e para o mercado de uma só vez. Por que não dizer que a juventude da "liturgia bronzeada" da Bola não está paradoxalmente feliz?

\section{Anexos}

Palavras que estão no site oficial da Bola de Neve Church:

A Igreja Bola de neve tem crescido em fé.

Porque nós sabemos que a FÉ é a única resposta que Deus espera de nós.

Estamos cientes que a Bíblia nos apresenta uma contracultura, e abraçá-la é redefinir a vida. ${ }^{9}$

Letras de músicas da Bola de Neve Church (A Bola de Neve realizou um desfile no carnaval de 2018). Samba-enredo:

\footnotetext{
${ }^{9}$ Disponível em <www.boladeneve.com>. Acesso em 14 de set. de 2018.
} 
Religare, ISSN: 19826605, v.15, n.2, dezembro de 2018, p.451-482.

Recebe o amor de Deus confia Vem pela fé a salvação de nossas vidas

O Rei desceu do céu, morreu na cruz por nós Jesus é meu super herói

Jesus Cristo o teu poder

Provem do Alto e não é ficção

Como os heróis da história em quadrinhos

E seriados da televisão

Deus é o dono do poder

Desde a criação do mundo ele era ele é

Levantando heróis tementes e de orações

E a sua igreja vai contar como é que é

Na bíblia diz

Na bíblia diz sobre os heróis da fé

De Noé o obediente ao governador José

Moisés com Deus abriu o mar está escrito

Dando liberdade ao povo escravizado no Egito

Deus no deserto deu pão que foi caindo do céu

E alimentou a nação o povo de Israel

Caíram muralhas pra Josué

Rumo a terra prometida liderando o povo em fé

\section{Caia Babilônia}

Os homens fazem a guerra

Depois tratam da paz

O que eles não percebem

É que o ontem ja foi e o amanhã nem chegou...

Por isso hoje viva e deixe viver

Vença a guerra dentro de você

Deixa o amor de Deus te ensinar a viver...

Peça ao Senhor chuva de primavera

Pois o Senhor é quem faz o trovão

E manda chuva pra plantação

É ele que da o fruto da terra ao homem

Para que ele se alegre com sua provisão 
Religare, ISSN: 19826605, v.15, n.2, dezembro de 2018, p.451-482.

Deus criou a terra, criou o mar

Pra que dela possa cuidar

Pra que eu possa cuidar

Será que isso irmão, não é suficiente pra você entender Que não tem o porque de adorar a criatura ao invés do Criador

Por isso hoje ouça o chamado de Deus

Ele nos chama de filhos Seu

Guerreiros na Babilonia, instrumentos do Seu amor

\section{O nosso General é Cristo.}

Pelo Senhor, marchamos sim

Seu exército poderoso é

Sua glória será vista em toda a Terra

Vamos cantar, o canto da vitória

Glória a Deus!

Vencemos a batalha

Toda a arma contra nós perecerá

O nosso general é Cristo

Seguimos os seus passos

Nenhum inimigo nos resistirá

Com o Messias, marchamos

Em suas mãos, a chave da vitória

Que nos leva a possuir a Terra prometida

Vamos cantar, o canto da vitória

Glória a Deus!

Vencemos a batalha

Toda a arma contra nós perecerá

Recebe o amor de Deus confia

Vem pela fé a salvação de nossas vidas

O Rei desceu do céu, morreu na cruz por nós

Jesus é meu super herói

Jesus Cristo o teu poder

Provem do Alto e não é ficção 
Religare, ISSN: 19826605, v.15, n.2, dezembro de 2018, p.451-482.

Como os heróis da história em quadrinhos

E seriados da televisão

Deus é o dono do poder

Desde a criação do mundo ele era ele é

Levantando heróis tementes e de orações

E a sua igreja vai contar como é que é

Na bíblia diz

Na bíblia diz sobre os heróis da fé

De Noé o obediente ao governador José

Moisés com Deus abriu o mar está escrito

Dando liberdade ao povo escravizado no Egito

Deus no deserto deu pão que foi caindo do céu

E alimentou a nação o povo de Israel

Caíram muralhas pra Josué

Rumo a terra prometida liderando o povo em fé

\section{Referências}

ALMEIDA, R. de.; MONTEIRO, Paula. Trânsito religioso no Brasil. In: São Paulo em Perspectiva, v. 15, n. 3, SP, Julho/Setembro 2001, p. 92-100.

BAUDRILLARD, Jean. Tela total: Mito-ironias da era do virtual e da imagem. Porto Alegre: Sulina, 2002.

BURJACK, Guilherme. O discurso neopentecostal como forma de dominação legal. In.: NETO, J.O R. Autoridade e Poder. Ensaios interdisciplinares de História do Cristianismo. SP: Reflexão, 2013, p. 89-102.

CAMPOS, S. L. As origens norte-americanas do pentecostalismo brasileiro: observações sobre uma relação ainda pouco avaliada. Revista USP, São Paulo, n. 67, p. 100-115, 2005.

CHARLES, Sébastien.; LIPOVETSKY, Gilles. Os tempos hipermodernos. São Paulo: Barcarolla, 2004.

COSTA, Renato de Lima da. Fora do indivíduo há salvação? A ética do pós-dever e a religião. In.: Gilles Lipovvetsky. Curitiba: Prismas, 2015.

DANTAS, Bruna S. do Amaral. A dupla linguagem do desejo na Igreja Bola de Neve. 2010, v. 30, n. 1, pp. 53-80.

DEMUNER, Angelo da Conceição. O neopentecostalismo e a formação da bancada evangélica no Brasil. O destaque dos neopentecostais dentro do cenário político brasileiro. In: Ensaio monográfico apresentado ao curso de História da Faculdade Saberes, 2013. 
Religare, ISSN: 19826605, v.15, n.2, dezembro de 2018, p.451-482.

ELIADE, Mircea. Tratado de História das Religiões. SP: M. Fontes, 2010.

FAUSTINO, T. Religiões no Brasil. Petrópolis: Vozes, 2011.

FERREIRA, Manuela Lowenthal. Maranhão Filho, E. M. de A. A grande onda vai te pegar. In: Horizonte, BH, v.12, n.33, p.270-276, jan/mar. 2014.

LIPOVETSKY, Gilles. A felicidade paradoxal: ensaios sobre a sociedade de hiperconsumo. SP: Companhia das Letras, 2007.

- A sociedade pós-moralista. O crepúsculo do dever e a ética indolor dos novos tempos democráticos. São Paulo: Manole, 2005.

. O império do efêmero. A moda e seu destino nas sociedades modernas. São Paulo: Companhia das letras, Coleção companhia de bolso, 2009.

. Os tempos hipermodernos. SP: Barcarolla, 2004.

LIPOVETSKY, G.; ROUX, E. O luxo eterno: Da idade do sagrado ao tempo das marcas. São Paulo: Companhia das Letras, 2005.

LIPOVETSKY, Gilles.; SERROY, Jean. A cultura mundo. Resposta a uma sociedade desorientada. São Paulo: Companhia das letras, 2011.

MARANHÃO, F. Eduardo Meinberg de Albuquerque. A Grande onda vai te pegar. Marketing, espatéculo e ciberespaço na Bola de Neve Church. São Paulo: Fonte Editorial, 2013.

MARIANO, Ricardo. Experiência pentecostal no Brasil. Estudos avançados, vol. 18, n. 52, SP, sept-dec. 2004.

MARIANO, Ricardo. Neopentecostais: Sociologia do novo pentecostalismo no Brasil. 3. ed. São Paulo: Ed. Loyola, 2010.

MATOS, A. S. Experiência pentecostal no Brasil. O caso da Igreja Universal. Estudos avançados, vol. 18, n. 52, SP, Sept-Dec. 2004.

- O Movimento Pentecostal: reflexões propósito do seu primeiro centenário. Fides Formata XI, São Paulo, v. 11, n. 2, p. 23-50, 2006. Disponível em:

$<$ http://www.mackenzie.br/fileadmin/Mantenedora/CPAJ/revista/VOLUME _XI__2006__2/Alderi.pdf $>$. Acesso em: 22 nov. de 2013.

MATOS, Alderi Souza. Raízes históricas da Teologia da prosperidade. Revista Ultimato, Julho-Agosto 2008.

MCALISTER, Walter. Neopentecostalismo - A história não contada: quem foi Roberto McAlister, conhecido como pai desse movimento. Rio de janeiro: Ed. Anno Domini, 2012.

MEIRELES, Tiago; LEMES, Fernando Lobo. A dinâmica religiosa dos fiéis: Neopentecostalismo e relações de consumo. In.: Caminhos, Goiânia, v. 15, n. 2, p. 313-329, jul/dez. 2017.

MESQUITA, Wania Amélia Belchior. Um pé no reino e outro no mundo: consumo e lazer entre pentecostais. In. Horizontes Antropológicos, v. 13, n. 28, Porto Alegre, 2007.

MONTES, Maria Lucia. As figuras do sagrado: entre o público e o privado. In: SCWARCZ, L. M. (organizadora). História da Vida Privada no Brasil : contrastes 
Religare, ISSN: 19826605, v.15, n.2, dezembro de 2018, p.451-482.

da intimidade contemporânea, São Paulo: Companhia das Letras, 1998 ( História da Vida Privada no Brasil, 4), p. 64-171.

ORO, Ari Pedro; RODRIGUES, Donizete. Transnacionalização religiosa: Religiões em movimento. Porto Alegre: Mídia, Religião e Sociedade, 2015.

PASSOS, João Décio. Ser como Deus. Críticas sobre as relações entre religião e mercado. In: BAPTISTA, Paulo Agostinho N.; SANCHEZ, Wagner Lopes (Orgs.). Teologia e sociedade. Relações, dimensões e valores éticos. São Paulo: Paulinas, 2011.

PASSOS, João Décio.; VILHENA, Maria Ângela (Orgs.). Religião e consumo. Relações e discernimentos. São Paulo: Paulinas, 2012.

PARAVIDINI, J. L. L.; GONÇALVES,M.A. Neopentecostalismo: desamparo e condição masoquista. Revista Mal estar e subjetividade, v. 9, n. 4, Fortaleza, dez2009.

RODRIGUES, Donizete. Deus, o demônio e o homem: o fenômeno Igreja Universal do Reino de Deus. Lisboa: Colibri, 1999.

. The God of the New Millennium: An introduction to the sociology of religion. Lisboa: Colibri, 2002.

.Em nome de Deus: A religião na sociedade contemporânea. Porto: Afrontamento, 2004.

.Jesus in sacred gotham: Brazilian immigrants and pentecostalism in New York city, Editora: Create Space Independent Publishing Platform, 2014. .O evangélico imigrante: O pentecostalismo brasileiro salvando a América. SP: Fonte Editorial, 2016.

SAQUETTO, Diemerson. A invenção do pastor político: Imaginários de poder político a partir da história das bancadas evangélicas. 2007. Dissertação (Mestrado em História) - Programa de Pós-Graduação em História Social das Relações Políticas - Universidade Federal do Espírito Santo, Vitória.

Recebido em 15-10-2018.

Aprovado em 20-01-2019. 